\title{
Serological evidence of exposure to Toxoplasma gondii and Neospora caninum in free-ranging Orinoco goose (Neochen jubata) in Brazil
}

\author{
Evidência sorológica de exposição à Toxoplasma gondii e Neospora caninum em Ganso-do-Orinoco \\ (Neochen jubata) de vida livre no Brasil \\ Marcos Rogério André ${ }^{1 *}$ (1); Mariele De Santi ${ }^{1,2}$; Mayara de Cássia Luzzi ${ }^{1}$; Juliana Paula de Oliveira²; \\ Simone de Jesus Fernandes ${ }^{1}$; Rosangela Zacarias Machado'; Karin Werther ${ }^{2}$

\begin{abstract}
${ }^{1}$ Laboratório de Imunoparasitologia, Departamento de Patologia Veterinária, Faculdade de Ciências Agrárias e Veterinárias - FCAV, Universidade Estadual Paulista - UNESP, Jaboticabal, SP, Brasil

${ }^{2}$ Laboratório de Patologia de Animais Selvagens, Departamento de Patologia Veterinária, Faculdade de Ciências Agrárias e Veterinárias - FCAV, Universidade Estadual Paulista - UNESP, Jaboticabal, SP, Brasil
\end{abstract}

Received June 26, 2019

Accepted September 5, 2019

\begin{abstract}
Toxoplasma gondii and Neospora caninum are Apicomplexan intracellular protozoan parasites that affect numerous animal species, thus leading to severe diseases and economic losses, depending on the vertebrate species involved. The role of the avian species in maintaining and transmission of these coccidia has been studied for several years as they tend to serve as a potential source of infection for mammals and humans. The present study aimed to assess the serological exposure of Orinoco goose (Neochen jubata) to T. gondii and N. caninum. Between 2010 and 2013, 41 free-ranging Orinoco geese were captured in the Araguaia River, Brazil. The presence and titration of IgY antibodies to both coccidia were assayed via indirect immunofluorescent antibody test (IFAT). While IgY antibodies for $N$. caninum were present in 5 animals, with titers of 20, the antibodies for $T$. gondii were found in 35 animals, with titers ranging from 20 to 640 . Considering that the Orinoco goose's meat is consumed by the local population in the studied area, it may represent an important source of $T$. gondii infection for humans. Due to its migratory behavior, this goose may play a pivotal role in the natural dispersion of both parasites. Furthermore, molecular studies are required for genotyping the isolates of T. gondii that occurs in this avian species.
\end{abstract}

Keywords: Orinoco goose, serology, toxoplasmosis, neosporosis.

\section{Resumo}

Toxoplasma gondii e Neospora caninum são parasitas protozoários intracelulares do philo Aplicomplexa que afetam uma vasta gama de espécies animais, causando sérias doenças e levando a perdas econômicas, dependendo da espécie envolvida. O papel das aves na manutenção e transmissão destes coccídios tem sido estudado por anos, já que eles são potenciais fontes de infecção para outros animais e humanos. $\mathrm{O}$ objetivo deste estudo foi avaliar a exposição do Ganso-do-Orinoco (Neochen jubata) a T. gondii e N. caninum por meio de técnicas sorológicas. Entre os anos de 2010 e 2013, 41 Gansos-do-Orinoco de vida livre foram capturados no Vale do Rio Araguaia, Brasil. A presença e titulação de anticorpos IgY para ambos os coccídios foi obtida utilizando-se a Reação de Imunofluorescência Indireta (RIFI). Enquanto a presença de anticorpos IgY para N. caninum foi detectada em 5 aves, com titulaçáo 20, anticorpos para T. gondii foram encontrados em 35 aves, com títulos variando de 20 a 640. Considerando que a carne do Ganso-do-Orinoco é uma fonte de alimento para a população da área estudada, a ave pode representar uma importante fonte de infecção de T. gondii para humanos. Devido ao seu comportamento migratório, esta espécie assume grande importância na dispersão de ambos os parasitas. Estudos moleculares são necessários a fim de caracterizar genotipicamente os isolados de T. gondii que ocorrem nesta espécie de ave.

Palavras-chave: Ganso-do-Orinoco, sorologia, toxoplasmose, neosporose.

\section{*Corresponding author: Marcos Rogério André . Laboratório de}

Imunoparasitologia, Departamento de Patologia Veterinária, Faculdade de Ciências

Agrárias e Veterinárias, Universidade Estadual Paulista - UNESP, Campus de

Jaboticabal, Via de Acesso Prof. Paulo Donato Castellane, s/n, Zona Rural,

CEP 14884-900, Jaboticabal, SP, Brasil. e-mail: mr.andre@unesp.br 
Toxoplasma gondii and Neospora caninum are Apicomplexan intracellular protozoan parasites that affect various animal species (DUBEY, 1986; DUBEY et al., 1988). Both parasites are responsible for causing severe diseases, being an important cause of abortion, leading to economic losses in the production system (MASALA et al., 2003). Despite the morphological similarities, T. gondii and $N$. caninum present distinct biological properties (INNES \& MATTSSON, 2007). The canids are the definitive hosts for $N$. caninum (MCALLISTER et al., 1998; DUBEY \& SCHARES, 2011), which affect mainly cattle and dogs and are not considered as an important zoonotic agent; whereas, felines are the definitive hosts for T. gondii (DUBEY, 2009), which affect several warm-blooded animals, causing reproductive disorders in small ruminants and humans (DUBEY et al., 2002).

Domestic and wild felids play a pivotal role in the epidemiology of T. gondii infection as they produce and shed resistant oocysts responsible for the perpetuation of the environmental contamination (DUBEY, 2009). Similar to humans, animals can be infected horizontally, ingesting T. gondii tissue cyst from the preys or oocysts from the contaminated environment, as well as vertically, through transplacental transmission. Besides being a good indicator of the environmental contamination with parasite oocysts, birds can serve as a potential source of Toxoplasma infection for humans (BÁRTOVÁ et al., 2009). Additionally, toxoplasmosis has been associated with mortality in certain avian species, such as doves (Columba livia) and canaries (Serinus canarius) (DUBEY, 2002). Since the early 1900, T. gondii infected several avian species, showing the high prevalence of this parasite worldwide (DUBEY, 2002).

Neospora caninum has a limited host range compared to T. gondii and causes diseases in different host species (DUBEY \& SCHARES, 2011). Distinct from T. gondii, N. caninum only recently has been investigated to cause infection in avian species, and few reports are available on natural infections, with immunohistochemistry and/or molecular assays demonstrating the presence of the parasite in brain and/or muscle of chickens (Gallus gallus), crows (Corvus cornix and C. monedula) sparrows (Passer domesticus), Red-and-green macaws (Ara chloropterus), Amazon parrots (Amazona aestiva), magpies (Pica pica), and common buzzards (Buteo buteo) (COSTA et al., 2008; GONDIM et al., 2010; MINEO et al., 2011; DARWICH et al. 2012; SALANT et al., 2015).

As the Toxoplasma and Neospora infections in avian have gained immense interest by researchers, the molecular and serologic tests have revealed that avian species play a pivotal role as intermediate hosts for both parasites. The employment of both techniques expanded the knowledge about the parasites' host range (DUBEY, 2002; BARROS et al., 2018). The present study aimed to detect antibodies for $T$. gondii and $N$. caninum in the serum samples of free-ranging Orinoco goose (Neochen jubata).

This project was approved by the Ethics Committee on Animal Use of the School of Agricultural and Veterinarian Sciences (FCAV/Unesp) under the protocol number 012273/11 and by Institute Chico Mendes for Conservation of Biodiversity (ICMBio) under the permission number 21650-4.

In the years 2010 and 2013, during the molting period, when geese became flightless, 41 free-ranging Orinoco geese were captured in the Araguaia River, state of Goiás, Brazil (13 ${ }^{\circ} 13^{\prime} 02.1^{\prime \prime} \mathrm{S}$ $\left.50^{\circ} 34^{\prime} 37.8^{\prime \prime W}\right)$. After the birds were manually restrained, whole blood samples were collected in tubes without anticoagulant by ulnar vein puncturing. After that, the geese were released in the same places where they were captured. The samples were centrifugated for 5 minutes at 5,000 rpm to obtain serum, and then stored at $-20{ }^{\circ} \mathrm{C}$ until further analysis.

In order to detect the IgY antibodies of T. gondii and $N$. caninum, the serum of each goose was subjected to indirect fluorescent antibody test (IFAT), as previously described (ANDRÉ et al., 2010). Neospora caninum NC-1 strain (DUBEY et al., 1988; MINEO et al., 2009) and T. gondii RH strain tachyzoites (DOMINGUES et al., 1998) were used as antigens in the serological reactions. Antigen slides were removed from storage and were allowed to thaw at room temperature for $30 \mathrm{~min}$. Thereafter, $10 \mu \mathrm{L}$ of sera at a dilution of 1:20 (cut-off for both $N$. caninum and $T$. gondii) were placed in wells on the antigen slides. Bird serum samples, positive and negative for $T$. gondii and $N$. caninum, obtained from the serum bank of the Laboratory of Immunoparasitology (VITALIANO et al., 2010; MINEO et al., 2009), Department of Veterinary Pathology of UNESP at Jaboticabal, SP, Brazil, were also used in the serological reactions. Slides were incubated at $37^{\circ} \mathrm{C}$ in a moist chamber for $45 \mathrm{~min}$, washed thrice in phosphate-buffered saline ( $\mathrm{pH} \mathrm{7.2)}$ for $5 \mathrm{~min}$, and were then air-dried at room temperature. Immunoglobulin $\mathrm{G}$ ( $\mathrm{IgG}$ ) anti-chicken conjugate (whole molecule with fluorescein isothiocyanate, dilution of 1:32; Sigma , St. Louis, Missouri) was diluted according to the manufacturer's instructions and added to each well. This conjugate has showed cross-reactivity with different IgY from several avian species (CRAY \& VILLAR, 2008; JUSTIZ VAILLANT et al., 2013). The slides were incubated, washed and dried, as above described. After that, they were overlaid with buffered glycerin ( $\mathrm{pH}$ 8.7), covered with glass coverslips, and examined using an epifluorescence microscope (Olympus, Japan).

Of the 41 serum samples of Orinoco goose analyzed via IFAT, $35(85.3 \%)$ presented IgY antibodies for T. gondii, with titers of $20(n=21), 40(n=10), 80(n=1), 160(n=1), 320(n=1)$, and $640(n=1)$; whereas, $5(12.1 \%)$ revealed $\operatorname{IgY}$ antibodies to $N$. caninum, with titers of 20 . The five animals positive for $N$. caninum were also positive for $T$. gondii, with titers of $20(n=3)$, $40(n=1)$, and $160(n=1)$. None of the geese presented antibodies for only $N$. caninum.

Orinoco goose belongs to Anatidae family and it is widely distributed in South America. In Brazil, this species is present in central and Amazon regions (ENDO et al., 2014). These geese are terrestrial grazers that live in pairs or in families, joining big groups during the molt. They present migratory behavior, moving in an expressive longitudinal direction inside the Amazon Basin, and eventually reaching the Llanos de Moxos, in north Bolivia (DAVENPORT et al., 2012). The species is classified as near threatened, as the geese count is reducing due to the hunting pressure and habitat loss for livestock and husbandry (BRESSAN et al., 2009).

Herein, it was demonstrated that the sampled Orinoco geese presented antibodies against $N$. caninum and T. gondii, suggesting previous contact with the parasites. Antibodies against $N$. caninum have also been described in common ravens (Corvus corax) in Spain and Israel, with prevalence rates of $35,8 \%$ and $16,4 \%$, respectively (MOLINA-LÓPEZ et al., 2012; SALANT et al., 2015), and in 
ducks and mallards (Anas sp.) in Italy, with prevalence of 34\% (ROCCHIGIANI et al., 2017). Antibodies against T. gondii have been previously described in geese and ducks in the Czech Republic with prevalence of 43\% (BÁRTOVÁ et al., 2009), as well as in China, with prevalence ranging from $4.7 \%$ to $17 \%$ (YAN et al., 2011, YANG et al., 2012; RONG et al. 2014). In Brazil, several studies have been performed considering the serological exposure of avian species to T. gondii (GONDIM et al., 2010; GENNARI et al., 2014; FEITOSA et al., 2017) and N. caninum (summarized by BARROS et al., 2018), demonstrating that these agents are widely distributed among the native wild avian species, in both free-ranging and captive specimens. A survey performed in Brazil detected antibodies to $T$. gondii and $N$. caninum in captive and free-living geese (Anser sp.), with prevalence rates lower than that presented in the present study $(18 \%$ and $0.67 \%$, respectively, $\mathrm{n}=149$ ). While the titers for T. gondii in that study (150) were also lower than those found in the present study, the titers for $N$. caninum were slightly higher (25) (KONELL et al., 2019). To the best of our knowledge, this is the first serological evidence of exposure to T. gondii and N. caninum in the Orinoco goose.

Avian species that feed directly from the soil, such as sparrows, chicken, doves, and geese, are exposed to infection by coccidial parasites, and may indicate the presence of $N$. caninum and T. gondii in the environment. Previous studies related to the presence of avian species on dairy farms with increasing seroprevalence and reproductive issues were associated with $N$. caninum infection in cattle, suggesting that these birds may play a pivotal role in parasite dispersion in the environment (OTRANTO et al., 2003). Moreover, certain avian species may be preyed by canids and felids, thus contributing to the transmission of both parasites (GONDIM et al., 2010). Due to its migratory behavior, the Orinoco goose may gain immense importance in studies exploring the natural dispersion of parasites.

The occurrence of neosporosis in avian species is less explored. While the clinical symptoms during natural infections have not been reported, the results of the experimental infections contribute to the present knowledge related to pathogenesis (BARROS et al., 2018). Although infection with $N$. caninum has been identified in several avian species via immunological and molecular techniques, to date, no viable parasites have been isolated (BARROS et al., 2018). This may be related to the higher body temperature of the birds since previous studies have reported that $N$. caninum tachyzoites were unable to grow in vitro at temperatures between $39^{\circ} \mathrm{C}$ and $41.5^{\circ} \mathrm{C}$ (REZENDE-GONDIM et al., 2017). In the present study, the prevalence of antibodies for $N$. caninum was lower than that found for $T$. gondii. This could be explained by the transient detectable antibodies, as previously described in crested caracaras (Caracara plancus) and chickens (Gallus gallus), experimentally infected with $T$. gondii and $N$. caninum, respectively, suggesting a different kinetics for the immune-humoral response in birds (FURUTA et al., 2007; VITALIANO et al., 2010).

Considering that the genomes of $T$. gondii and $N$. caninum present similarities in size and in the protein groups involved in biological functions (LORENZI et al., 2016), cross-reactivity may be observed in the serological tests. The IFAT revealed higher specificity when compared to the enzyme-linked immunosorbent assay (ELISA) during antibody detection for these parasites in the dog sera (HIGA et al., 2000). In particular, the IFAT has been previously demonstrated to be specific for the diagnosis of neosporosis in mammals, with no cross-reactivity with $T$. gondii, using polyclonal antisera obtained from rabbits (DUBEY et al., 1996). Dilutions of 1:50 or higher have been found to be appropriate to avoid cross-reactivity between $N$. caninum and $T$. gondii in the dog sera (HIGA et al., 2000; SILVA et al., 2007) and humans (LOBATO et al., 2006) using IFAT. Noteworthily, the avian species reveals a different kinetics for the immune-humoral response, which may influence the antibody titers. Chickens and crested caracaras experimentally infected with $N$. caninum and $T$. gondii, respectively, presented peak IgG production between 15 and 30 days post infection, with negative antibody detection after 2 months of infection in chickens and 45 days of infection in the crested caracaras (FURUTA et al., 2007; VITALIANO et al., 2010). Pigeons (Columba livia) experimentally infected with T. gondii presented IgG profiles similar to those infected with $N$. caninum, although the antibody titers were higher in $T$. gondii-infected pigeons during acute phase (MINEO et al., 2009). In that work, the authors also reported the lack of serological cross-reactions between the antibodies for $T$. gondii and $N$. caninum, even at dilutions of 1:20 with IFAT (MINEO et al., 2009). In this study, we found five $N$. caninum-seropositive geese, using a cutoff of 1:20. Considering the short duration of antibody titers in the avian species, as demonstrated in previous experimental studies, whether a higher cutoff had been used, antibodies for $N$. caninum might not have been detected. However, it is noteworthy that a second serological test would confirm the evidence of serological exposure to $N$. caninum in the sampled Orinoco geese.

Although antibodies against $N$. caninum have been described in several hosts, including humans, the zoonotic potential remains unclear, since no reports are available on the clinical infections in humans. Presumably, the cases of human neosporosis have been misdiagnosed as toxoplasmosis, as the infection by $N$. caninum in healthy individuals may follow a course similar to that of T. gondii, with most infections being asymptomatic (TRANAS et al., 1999). Previously, the antibodies for $N$. caninum were detected predominantly in the HIV-infected patients and those with neurological disorders, whereas newborns and healthy subjects presented lower seropositivity rates (LOBATO et al., 2006).

EDTA-blood samples from the same geese of the present study have been previously analyzed by molecular assays targeting arthropod-borne agents, which showed the presence of genetic material of Ehrlichia, Anaplasma, Babesia, Plasmodium, and Haemoproteus (WERTHER et al., 2017). The coifection with several parasite species might lead to impairment in the avian health, making them more susceptible to be preyed by a carnivorous animal, or caught by human.

It is known that the Orinoco geese are consumed as a food source by the local population. Although there could be several sources of $T$. gondii infection in humans residing in that area, a survey on the seroprevalence for $T$. gondii in the local population may be helpful in understanding the role of this anatid species in the transmission of toxoplasmosis in the local population. Toxoplasmosis is a zoonotic health issue, and therefore, the population should be aware of the risk of encountering this parasite when exposed to the infected avian species. 
Presently, the molecular and serological studies have revealed that $N$. caninum and $T$. gondii have numerous intermediate hosts. Birds, in particular, may contribute to the dissemination of both parasites. Furthermore, studies on different avian species, with the isolation and molecular genotyping of these agents are needed, in order to understand the real importance of these birds in the epidemiology and ecology of the aforementioned diseases, thus aiming to control them and decrease their health and economic impact.

\section{Acknowledgements}

MRA and RZM are fellowship researchers of "Conselho Nacional de Desenvolvimento Científico e Tecnológico" (CNPq Process number \#302420/2017-7 and \#306326/2014-0).

\section{References}

André MR, Adania CH, Teixeira RHF, Silva KF, Jusi MMG, Machado STZ, et al. Antibodies to Toxoplasma gondii and Neospora caninum in Captive Neotropical and Exotic Wild Canids and Felids. J Parasitol 2010; 96(5): 1007-1009. http://dx.doi.org/10.1645/GE-2502.1. PMid:20950109.

Barros LD, Miura AC, Minutti AF, Vidotto O, Garcia JA. Neospora caninum in birds: A review. Parasitol Int 2018; 67(4): 397-402. http:// dx.doi.org/10.1016/j.parint.2018.03.009. PMid:29614327.

Bártová E, Sedlák K, Literák I. Serologic survey for toxoplasmosis in domestic birds from the Czech Republic. Avian Pathol 2009; 38(4): $317-$ 320. http://dx.doi.org/10.1080/03079450903055405. PMid:19937517.

Bressan PM, Kierulff MCM, Sugieda AM. Fauna ameaçada de extinção no estado de São Paulo: vertebrados. São Paulo: Fundaçáo Parque Zoológico de São Paulo, Secretaria do Meio Ambiente; 2009.

Costa KS, Santos SL, Uzêda RS, Pinheiro AM, Almeida MAO, Araújo FR, et al. Chickens (Gallus domesticus) are natural intermediate hosts of Neospora caninum. Int J Parasitol 2008; 38(2): 157-159. http://dx.doi. org/10.1016/j.ijpara.2007.10.008. PMid:18054356.

Cray C, Villar D. Cross-reactivity of anti-chicken IgY antibody with immunoglobulins of exotic avian species. Vet Clin Pathol 2008; 37(3): 328-331. http://dx.doi.org/10.1111/j.1939-165X.2008.00055.x. PMid:18761528.

Darwich L, Cabezón O, Echeverria I, Pabón M, Marco I, Molina-López $\mathrm{R}$, et al. Presence of Toxoplasma gondii and Neospora caninum DNA in the brain of wild birds. Vet Parasitol 2012; 183(3-4): 377-381. http:// dx.doi.org/10.1016/j.vetpar.2011.07.024. PMid:21831525.

Davenport LC, Bazán IN, Erazo NC. East with the Night: Longitudinal Migration of the Orinoco Goose (Neochen jubata) between Manú National Park, Peru and the Llanos de Moxos, Bolivia. PLoS One 2012; 7(10): e46886. http://dx.doi.org/10.1371/journal.pone.0046886. PMid:23056512.

Domingues LM, Machado RZ, Costa MT, Carvalho CS, Costa AJ, Malheiros EB. Canine toxoplasmosis: A comparative evaluation of the detection of anti-Toxoplasma gondii antibodies by the indirect immunoenzymatic assay (ELISA) and indirect immunofluorescent reaction (IIF). Rev Bras Parasitol Vet 1998; 7(2): 79-85.

Dubey JP, Barr BC, Barta JR, Bjerkas I, Bjorkman C, Blagburn BL, et al. Redescription of Neospora caninum and its differentiation from related coccidia. Int J Parasitol 2002; 32(8): 929-946. http://dx.doi.org/10.1016/ S0020-7519(02)00094-2. PMid:12076623.

Dubey JP, Hattel AL, Lindsay DS, Topper MJ. Neonatal Neospora caninum infection in dogs: isolation of the causative agent and experimental transmission. J Am Vet Med Assoc 1988; 193(10): 1259-1263. PMid:3144521.

Dubey JP, Lindsay DS, Adams DS, Gay JM, Baszler TV, Blagburn BL, et al. Serologic responses of cattle and other animals infected with Neospora caninum. Am J Vet Res 1996; 57(3): 329-336. PMid:8669764.

Dubey JP, Schares G. Neosporosis in animals-The last five years. Vet Parasitol 2011; 180(1-2): 90-108. http://dx.doi.org/10.1016/j.vetpar.2011.05.031. PMid:21704458.

Dubey JP. Toxoplasmosis. J Am Vet Med Assoc 1986; 189(2): 166-170. PMid:3528098.

Dubey JP. A review of toxoplasmosis in wild birds. Vet Parasitol 2002; 106(2): 121-153. http://dx.doi.org/10.1016/S0304-4017(02)00034-1. PMid:12031816.

Dubey JP. Toxoplasmosis of animals and humans. 2nd ed. Florida: CRC Press; 2009.

Endo W, Haugaasen T, Peres CA. Seasonal abundance and breeding habitat occupancy of the Orinoco goose (Neochen jubata) in western Brazilian Amazonia. Bird Conserv Int 2014; 24(4): 518-529. http:// dx.doi.org/10.1017/S0959270914000173.

Feitosa TF, Brasil AWL, Parentoni RN, Vilela VLR, Nety TFL, Pena HFJ. Anti-Toxoplasma gondii antibodies in mammals, birds and reptiles at the zoological-botanical park in João Pessoa, Paraíba, Brazil. Arq Inst Biol (Sao Paulo) 2017; 84(1-5): e0022016. http://dx.doi.org/10.1590/18081657000022016

Furuta PI, Mineo TW, Carrasco AO, Godoy GS, Pinto AA, Machado RZ. Neospora caninum infection in birds: experimental infections in chicken and embryonated eggs. Parasitol 2007; 134(4): 1931-1939. http://dx.doi. org/10.1017/S0031182007003344. PMid:17686190.

Gennari SM, Ogrzewalska M, Soares HS, Saraiva DG, Pinter A, Labruna MB, et al. Occurrence of Toxoplasma gondii antibodies in birds from the Atlantic Forest, state of São Paulo, Brazil. Vet Parasitol 2014; 200(1-2): 193-197. http://dx.doi.org/10.1016/j.vetpar.2013.10.003. PMid:24332961.

Gondim LSQ, Abe-Sandes K, Uzêda RS, Silva MSA, Santos SL, Mota RA, et al. Toxoplasma gondii and Neospora caninum in sparrows (Passer domesticus) in the Northeast of Brazil. Vet Parasitol 2010; 168(1-2): 121 124. http://dx.doi.org/10.1016/j.vetpar.2009.09.055. PMid:19879051.

Higa AC, Machado RZ, Costa MT, Domingues LM, Malheiros EB. Evaluation of cross-reactivity of Toxoplasma gondii and Neospora caninum antigens in dogs sera. Rev Bras Parasitol Vet 2000; 9(2): 91-95.

Innes EA, Mattsson JG. Neospora caninum emerges from the shadow of Toxoplasma gondii. Trends Parasitol 2007; 23(2): 43-44, discussion 44-45. http://dx.doi.org/10.1016/j.pt.2006.12.004. PMid:17185039.

Justiz Vaillant AA, Ramirez N, Cadiz A, Ferrer B, Akpaka P, Smikle M. Separation and Reactivity of Avian Immunoglobulin Y.J Chromatogr Sep Tech 2013; 4(03): 173. http://dx.doi.org/10.4172/2157-7064.1000173.

Konell AL, Sato AP, Stival M, Malaguini NP, Anjos A, Ferreira RF, et al. Serosurvey of Toxoplasma gondii, Sarcocystis sp. and Neospora caninum in geese (Anser sp.) from urban parks and captivity. Rev Bras Parasitol Vet 2019; 28(2): 221-228. http://dx.doi.org/10.1590/s1984-29612019042. PMid:31271639. 
Lobato J, Silva DAO, Mineo TWP, Amaral JDHF, Segundo GRS, Costa-Cruz JM, et al. Detection of Immunoglobulin G Antibodies to Neospora caninum in Humans: High Seropositivity Rates in Patients Who Are Infected by Human Immunodeficiency Virus or Have Neurological Disorders. Clin Vaccine Immunol 2006; 13(1): 84-89. http://dx.doi. org/10.1128/CVI.13.1.84-89.2006. PMid:16426004.

Lorenzi H, Khan A, Behnke MS, Namasivayam S, Swapna LS, Hadjithomas M, et al. Local admixture of amplified and diversified secreted pathogenesis determinants shapes mosaic Toxoplasma gondii genomes. Nat Commun 2016; 7(1): 10147. http://dx.doi.org/10.1038/ ncomms10147. PMid:26738725.

Masala G, Porcu L, Madau L, Tanda A, Ibba A, Satta G, et al. Survey of ovine and caprine toxoplasmosis by IFAT and PCR assays in Sardinia, Italy. Vet Parasitol 2003; 117(1-2): 15-21. http://dx.doi.org/10.1016/j. vetpar.2003.07.012. PMid:14597274.

McAllister MM, Dubey JP, Lindsay DS, Jolley WR, Wills RA, McGuire AM. Dogs are definitive hosts of Neospora caninum. Int J Parasitol 1998; 28(9): 1473-1478. http://dx.doi.org/10.1016/S0020-7519(98)00138-6. PMid:9770635.

Mineo TWP, Carrasco AOT, Marciano JA, Werther K, Pinto AA, Machado RZ. Pigeons (Columba livia) are a suitable experimental model for Neospora caninum infection in birds. Vet Parasitol 2009; 159(2): 149-153. http:// dx.doi.org/10.1016/j.vetpar.2008.10.024. PMid:19027237.

Mineo TWP, Carrasco AOT, Raso TF, Werther K, Pinto AA, Machado RZ. Survey for natural Neospora caninum infection in wild and captive birds. Vet Parasitol 2011; 182(2-4): 352-355. http://dx.doi.org/10.1016/j. vetpar.2011.05.022. PMid:21680099.

Molina-López R, Cabezón O, Pabón M, Darwich L, Obón E, LopezGatius F, et al. High seroprevalence of Toxoplasma gondii and Neospora caninum in the Common raven (Corvus corax) in the Northeast of Spain. Res Vet Sci 2012; 93(1): 300-302. http://dx.doi.org/10.1016/j. rvsc.2011.05.011. PMid:21645913.

Otranto D, Llazari A, Testini G, Traversa D, Frangipane di Regalbono A, Badan M, et al. Seroprevalence and associated risk factors of neosporosis in beef and dairy cattle in Italy. Vet Parasitol 2003; 118(1-2): 7-18. http:// dx.doi.org/10.1016/j.vetpar.2003.10.008. PMid:14651870.

Rezende-Gondim MM, da Silva AV, Schares G, Gondim LFP. In contrast to Toxoplasma gondii, Neospora caninum tachyzoites did not sustain multiplication in vitro at increased incubation temperatures. Vet Parasitol
2017; 234: 19-24. http://dx.doi.org/10.1016/j.vetpar.2016.12.013. PMid:28115178.

Rocchigiani G, Poli A, Nardoni S, Papini R, Mancianti F. Neospora caninum in Wild Waterfowl: Occurrence of Parasite DNA and Low antibody titers. J Parasitol 2017; 103(1): 142-145. http://dx.doi.org/10.1645/16-34. PMid:27805842.

Rong G, Zhou H, Hou G, Zhao J, Xu T, Guan S. Seroprevalence, risk factors and genotyping of Toxoplasma gondii in domestic geese (Anser domestica) in tropical China. Parasit Vectors 2014; 7: 459. http://dx.doi. org/10.1186/s13071-014-0459-9. PMid:25274416.

Salant H, Mazuz ML, Savitsky I, Nasereddin A, Blinder E, Baneth G. Neospora caninum in crows from Israel. Vet Parasitol 2015 212(3-4): 375-378. http://dx.doi.org/10.1016/j.vetpar.2015.08.019. PMid:26359640.

Silva DA, Lobato J, Mineo TW, Mineo JR. Evaluation of serological tests for the diagnosis of Neospora caninum infection in dogs: optimization of cut off titers and inhibition studies of cross-reactivity with Toxoplasma gondii. Vet Parasitol2007; 143(3-4): 234-244. http://dx.doi.org/10.1016/j. vetpar.2006.08.028. PMid:16973287.

Tranas J, Heinzen RA, Weiss LM, McAllister MM. Serological Evidence of Human Infection with the Protozoan Neospora caninum. Clin Diagn Lab Immunol 1999; 6(5): 765-767. PMid:10473533.

Vitaliano SN, Mineo TW, André MR, Machado RZ, Mineo JR, Werther K. Experimental infection of Crested Caracara (Caracara plancus) with Toxoplasma gondii simulating natural conditions. Vet Parasitol 2010; 172(1-2): 71-75. http://dx.doi.org/10.1016/j.vetpar.2010.04.010. PMid:20451327.

Werther K, Luzzi MC, Gonçalves LR, Oliveira JP, Alves JRF Jr, Machado RZ, et al. Arthropod-borne agents in wild Orinoco geese (Neochen jubata) in Brazil. Comp Immunol Microbiol Infect Dis 2017; 55: 30-41. http:// dx.doi.org/10.1016/j.cimid.2017.09.003. PMid:29127991.

Yan C, Yue CL, Zhang H, Yin CC, He Y, Yuan ZG, et al. Serological survey of Toxoplasma gondii infection in the domestic goose (Anser domestica) in southern China. Zoonoses Public Health 2011; 58(4): 299-302. http:// dx.doi.org/10.1111/j.1863-2378.2010.01349.x. PMid:20707861.

Yang N, Mu M, Li H, Long M, He J. Seroprevalence of Toxoplasma gondii infection in slaughtered chickens, ducks, and geese in Shenyang, northeastern China. Parasit Vectors 2012; 5(1): 237. http://dx.doi. org/10.1186/1756-3305-5-237. PMid:23078787. 